\title{
Evidence for Protein Tyrosine Phosphatase, Tyrosine Kinase, and G-Protein Regulation of the Parallel Fiber Metabotropic Slow EPSC of Rat Cerebellar Purkinje Neurons
}

\author{
Marco Canepari and David Ogden \\ National Institute for Medical Research, Mill Hill, London NW7 1AA, United Kingdom
}

\begin{abstract}
The slow EPSP (sEPSP) or slow EPSC (sEPSC) at parallel fiber to Purkinje neuron synapses is attributable to a nonselective cation channel coupled to activation of metabotropic type 1 glutamate receptors (mGluR1s). Photorelease of L-glutamate in $1 \mathrm{msec}$ from 4-methoxy-7nitroindolinyl- or 7-nitroindolinyl-caged glutamate in cerebellar slices was used to isolate and study postsynaptic mechanisms coupling mGluR1 to the cation channel. L-Glutamate immediately activated a glutamate transporter current, followed by the slow mGluR1activated conductance. Inhibitors of kinases, phosphatases, and G-proteins were tested on the peak glutamate-evoked currents. No effects of the inhibitors were seen on the initial glutamate transporter currents. In contrast, the later mGluR1 currents were either unaffected or enhanced by the protein tyrosine kinase (PTK) inhibitors PP1, K252a, and staurosporine were diminished or blocked by phosphatase inhibitors but were unaffected by inhibitors of serine-threonine kinases PKA, PKC, or PKG. The selective src-PTK inhibitor PP1 (10 $\mu \mathrm{M}$ intracellularly) potentiated submaximal mGluR1 currents evoked by low L-glutamate concentrations but had no effect on maximal responses (80 or $160 \mu \mathrm{M}$ L-glutamate). L-Glutamate-evoked mGluR1 currents and parallel fiber sEPSCs were reversibly and completely inhibited by protein tyrosine phosphatase (PTP) inhibitor bpV(phen) (50-200 $\mu \mathrm{M})$ and by nonselective phosphatase inhibitor orthovanadate $(0.5$ or $1 \mathrm{~mm})$. mGluR1 currents were completely inhibited by GDP $\beta$ S applied intracellularly $(5 \mathrm{~mm})$. The results confirm a role for a GTPase postsynaptically, show that tyrosine phosphorylation inhibits mGluR1 coupling to the channel, and show that PTPs increase activation by tyrosine dephosphorylation most likely upstream of the sEPSP cation channel.
\end{abstract}

Key words: cerebellum; Purkinje neuron; parallel fiber; slow EPSP; metabotropic glutamate receptor; tyrosine phosphorylation

\section{Introduction}

Parallel fibers (PFs) in the molecular layer are the principal excitatory input to Purkinje neurons (PNs) in the cerebellum of the rat, with $\sim 175,000$ excitatory synapses on postsynaptic spines of the dendritic tree (Napper and Harvey, 1988). Single PF stimuli evoke fast postsynaptic potentials, acting through glutamate AMPA-type receptors. However, brief tetanic stimulation produces a slow EPSP (sEPSP) seen in the presence or absence of AMPA receptor antagonists (Batchelor and Garthwaite, 1997). The sEPSP is blocked by metabotropic type 1 glutamate receptor (mGluR1) antagonists MCPG ( $\alpha$-methyl-4-carboxyphenylglycine) and CPCCOEt (7- (hydroxyimino)cyclopropa[b]chromen-1acarboxylate ethyl ester), and the postsynaptic depolarization is produced by activation of a nonselective cation channel (Canepari et al., 2001b). A role of mGluR1 receptors in motor coordination is suggested by observations that $\mathrm{mGluR} 1 \alpha$-deficient mice are ataxic, with lesions in the cerebellar molecular layer and developmental abnormalities in the innervation of PNs (Aiba et al., 1994). Also, clinical neoplastic cerebellar ataxia, in which there is a deficit in motor co-

\footnotetext{
Received Sept. 6, 2002; revised Feb. 6, 2003; accepted Feb. 6, 2003.

This work was supported by the Medical Research Council and a European Union Marie Curie Fellowship (M.C.) We thank Kobi Rosenblum for advice, John Corrie and George Papageorgiou (National Institute of Medical Research, London, UK) for advice and for providing NI and MNI caged glutamate, and (eline Auger for critical comments on this manuscript.

Correspondence should be addressed to Dr. David Ogden, National Institute for Medical Research, The Ridgeway London NW7 1AA, UK. E-mail: dogden@nimr.mrc.ac.uk.

Copyright $\odot 2003$ Society for Neuroscience $\quad$ 0270-6474/03/234066-06\$15.00/0
}

ordination, has been shown to be associated with autoantibodies generated against mGluR1 (Sillevis-Smitt et al., 2000).

mGluR1 receptors in PNs can couple to phospholipase C (PLC) via a G-protein. However, photorelease of intracellular inositol trisphosphate $\left(\mathrm{InsP}_{3}\right)$ does not mimic the sEPSP and instead produces activation of $\mathrm{K}^{+}$conductance by intracellular $\mathrm{Ca}^{2+}$ and a consequent reduction of excitability (Khodakhah and Ogden, 1995; Hirono et al., 1998). Furthermore, inhibition of PLC has no effect on the slow EPCS (sEPSC) (Hirono et al., 1998; Tempia et al., 1998; Canepari et al., 2001b). In the experiments described here, the postsynaptic signaling pathway was investigated by photorelease of L-glutamate from 4-methoxy-7nitroindolinyl (MNI)- or 7-nitroindolinyl (NI)-caged glutamate to activate the mGluR1 conductance (Papageorgiou et al., 1999; Canepari et al., 2001a). Glutamate was released in $1 \mathrm{msec}$ over $\sim 200 \mu \mathrm{m}$ region in cerebellar slices of 20 -d-old rats. Postsynaptic mGluR1 currents were isolated by the presence of AMPA receptor antagonists, and action potentials were suppressed by $\mathrm{Na}^{+}$ and $\mathrm{Ca}^{2+}$ channel blockers. The results with selective inhibitors show that protein tyrosine phosphorylation, but not serine-threonine phosphorylation, inhibits the mGluR1 sEPSP signaling pathway at a site before the ion channel and confirms the postsynaptic role of a G-protein (Tempia et al., 1998). Inhibition of protein tyrosine phosphatase (PTP) was able to suppress completely the mGluR1 and PF sEPSC.

Parts of this work have been published previously in abstract form (Canepari and Ogden, 2002). 


\section{Materials and Methods}

Wistar rats, 19-22 d old, were killed by cervical dislocation and decapitated, and parasagittal slices $200 \mu \mathrm{m}$ or transverse slices $350 \mu \mathrm{m}$ thick (in PF stimulation experiments) were cut from the cerebellum. Slices were viewed with a Zeiss (Oberkochen, Germany) Axioskop 1FS, $63 \times 0.9 \mathrm{w}$ objective and, to avoid photolysis, 500/40 nm bandpass illumination. A xenon arc flashlamp (Rapp OptoElektronik, Hamburg, Germany) filtered with a UG11 (bandpass 290-370 nm; Schott, Mainz, Germany) was focused into the slice from below via a Reichert (Nussloch, Germany) silica condenser ( 0.9 numerical aperture), illuminating a spot of $200 \mu \mathrm{m}$ in diameter The arc image was aligned and focused in the specimen plane, and calibration of photolytic conversion-flash was made as described by Canepari et al. (2001a). Transmission at $320 \mathrm{~nm}$ through 200 $\mu \mathrm{m}$ slices from 20 -d-old rats was measured as $0.42 \pm 0.07$ (SD) in the molecular layer and $0.36 \pm 0.08$ in the granule cell layer. Flash lamp intensity was set to maximum, converting in the molecular layer $7 \%$ of $\mathrm{NI}$ and $18 \%$ of MNI glutamate in a first set of experiments, or $32 \% \mathrm{MNI}$ glutamate in a second set, after correction for attenuation in the slice. Lower L-glutamate concentrations were produced by reducing intensity with calibrated neutral density filters in the photolysis light path.

External saline contained the following (in mM): $135 \mathrm{NaCl}, 4 \mathrm{KCl}, 2$ $\mathrm{MgSO}_{4}$ or $\mathrm{MgCl}_{2}, 2 \mathrm{CaCl}_{2}, 2 \mathrm{NaHCO}_{3}, 25$ glucose, and 10 HEPES-Na, $\mathrm{pH} 7.3(305 \mathrm{mOsm} / \mathrm{kg})$. Experiments were made at $32^{\circ} \mathrm{C}$, and a continuous stream of hydrated $\mathrm{O}_{2}-0.5 \% \mathrm{CO}_{2}$ was blown over the solution surface. Caged glutamate and antagonists were applied in static $1 \mathrm{ml}$ of solution. Whole-cell recordings were with an Axoclamp 2A or Axopatch 200A (Axon Instruments, Foster City, CA) and $2.5 \mathrm{M} \Omega$ pipettes filled with the following internal solution (in $\mathrm{mM}$ ): $110 \mathrm{~K}$ gluconate, 50 HEPES, $10 \mathrm{KCl}, 4 \mathrm{MgSO}_{4}, 4 \mathrm{Na}_{2} \mathrm{ATP}, 10$ creatine phosphate, $0.05 \mathrm{GTP}, \mathrm{pH}$ 7.3, with $\mathrm{KOH}$. Potentials were corrected for the junction potential of $12 \mathrm{mV}$ pipette negative between this solution and external solution. Series resistance was monitored at 5 min intervals, and experiments in which it increased above $10 \mathrm{M} \Omega$, or in which the leak current at $-75 \mathrm{mV}$ exceeded $-0.5 \mathrm{nA}$, were discontinued.

Data were collected with Spike 2 software via a $1401+$ or Power1401 interface (sampled $10 \mathrm{kHz}$, low-pass filter $2 \mathrm{kHz},-3 \mathrm{~dB}$; Cambridge Electronic Design, Cambridge, UK). Results are given as mean and SD unless specified as SEM.

Chemicals were Analar grade (BDH, Poole, UK), and biochemicals and drugs were obtained from Sigma (Poole, UK), Tocris (Bristol, UK) or Research Biochemicals (Poole, UK). Experiments with the Ca channel blocker $\omega$-Agatoxin IVA (AGA4A) (Peptide Institute, Osaka, Japan) were done with $0.1 \mathrm{mg} / \mathrm{ml}$ cytochrome $\mathrm{C}$ present. The concentration of $\mathrm{bpV}$ (phen) was determined from the absorbance at $326 \mathrm{~nm}$, and the extinction coefficient is $1206 \mathrm{M} / \mathrm{cm}$ (Quilitzsch and Wieghardt, 1979); a $100 \mathrm{~mm}$ stock ( $10 \mathrm{~mm}$ HEPES, $\mathrm{pH} 7.6$ ) was stored at $-80^{\circ} \mathrm{C}$.

NI- and MNI-caged L-glutamate were synthesized, purified, and kindly provided by John Corrie and George Papageorgiou (National Institute for Medical Research, London, UK). These reagents at $1 \mathrm{~mm}$ concentration, the photolytic intermediates, and byproducts have been shown to have no pharmacological activity on glutamate receptors or synaptic transmission (Canepari et al., 2001a).

\section{Results}

To isolate the mGluR1-evoked current, experiments were done with ionotropic glutamate receptor antagonists 2,3-dioxo-6nitro-1,2,3,4-tetrahydrobenzo[f] quinoxaline-7-sulfonamide (NBQX) (20-50 $\mu \mathrm{M})$ and 2-amino-5-phosphonopentanoic acid $(\mathrm{AP}-5)(50 \mu \mathrm{M})$ and of $\mathrm{GABA}_{\mathrm{A}}$ receptor antagonist bicuculline $(20 \mu \mathrm{M})$. In photolysis experiments, the voltage-gated sodium channel blocker tetrodotoxin (TTX) $(1 \mu \mathrm{M})$ was used, and the calcium channel blocker AGA4A $(0.25 \mu \mathrm{M})$ was present to prevent spiking during large mGluR1-activated inward current. Activation of the mGluR1 current was usually with supramaximal concentrations of L-glutamate, $70 \mu \mathrm{M}$ L-glutamate released from $1 \mathrm{~mm}$ NI glutamate, 80,90 , or $160 \mu \mathrm{m}$ from MNI glutamate, and, in some experiments, also submaximal activation with $30 \mu \mathrm{M}$

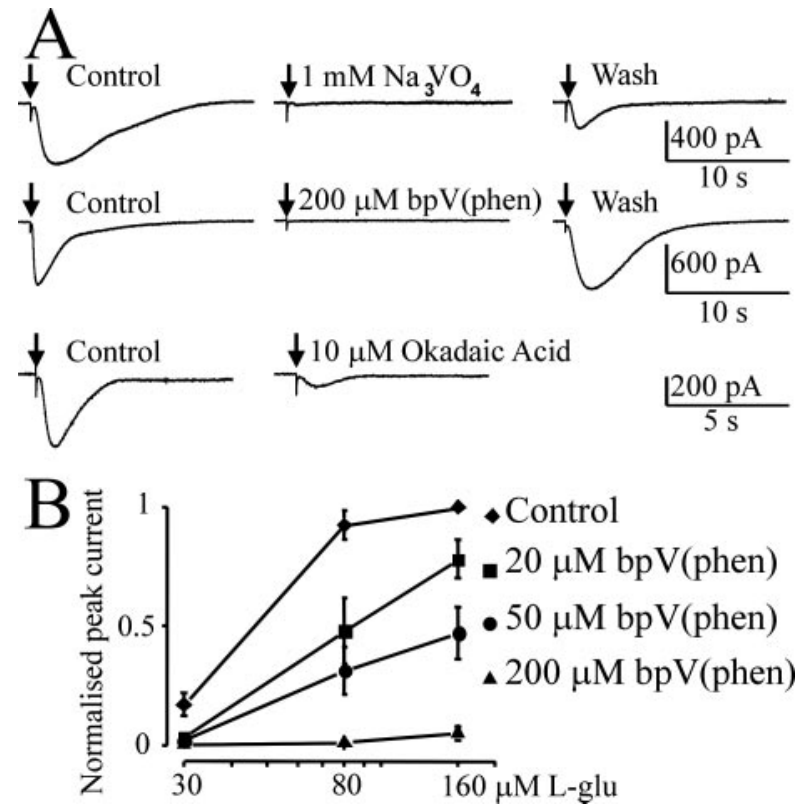

Figure 1. Inhibition of the mGluR1 current by extracellular application of phosphatase inhibitors. Voltage clamp, $-75 \mathrm{mV}$. The following concentrations were used: $50 \mu \mathrm{m} \mathrm{NBQX,50}$ $\mu \mathrm{M}$ AP-5, $20 \mu \mathrm{m}$ bicuculline, $1 \mu \mathrm{m}$ TTX, and $0.25 \mu \mathrm{m}$ AGA4A. A, Top traces, Currents evoked by $70 \mu \mathrm{m} \mathrm{L}$-glutamate in control solution, after 10 min exposure to $1 \mathrm{~mm} \mathrm{Na}_{3} \mathrm{VO}_{4}$, and after $20 \mathrm{~min}$ wash. Middle traces, Currents evoked by $80 \mu \mathrm{m} \mathrm{L-glutamate}$ in control solution, after $10 \mathrm{~min}$ exposure to $200 \mu \mathrm{m}$ tyrosine phosphatase inhibitor bpV(phen) and after $20 \mathrm{~min}$ wash. Bottom traces, Currents evoked by $70 \mu \mathrm{m} \mathrm{L}$-glutamate in control solution and after $10 \mathrm{~min}$ exposure to $10 \mu \mathrm{m}$ okadaic acid. No reversal on washing. B, Peak mGluR1 current plotted against L-glutamate concentration (30,80, or $160 \mu \mathrm{m}$; log scale). Peak current (mean \pm SEM) normalized to the peak current in each cell recorded initially with $160 \mu \mathrm{m}$ L-glutamate. Diamonds, Initial currents at each glutamate concentration. Squares, Circles, Triangles, Currents recorded after 20 min incubation in 20,50, and $200 \mu \mathrm{m} \mathrm{bpV(phen),} \mathrm{respectively} \mathrm{(4} \mathrm{or} 5$ cells at each concentration).

L-glutamate or less. The relationship between peak current and $\mathrm{L}$-glutamate concentration is shown in Figure $1 \mathrm{~B}$. These glutamate concentrations compare with the millimolar concentrations estimated at synaptic release sites; however, the concentrations and durations seen at more peripherally located mGluR1 during a PF tetanus is not known. Photoreleased L-glutamate adjacent to PNs in the slice was estimated to have a clearance half-time of $200 \mathrm{msec}$ at $70 \mu \mathrm{M}$ (Canepari et al., 2001b). The peak mGluR1 current at $-75 \mathrm{mV}$ was taken as a measure of the conductance attributable to the mGluR1-activated channel.

\section{Protein tyrosine kinase inhibition}

The trk tyrosine kinase inhibitor K252a (externally $10 \mu \mathrm{M}$ ) was initially used to test the possibility that the slow current recorded in PNs might be mediated by release of neurotrophins from glia as a consequence of glial mGluR1 activation. Neurotrophins produce an inward current in PNs, blocked by trk protein tyrosine kinase (PTK) inhibition (Kafitz et al., 1999). K252a showed no inhibition, indicating no contribution of an indirect action of glutamate on PNs by mGluR1-evoked release of neurotrophins from glia. However, a potentiation of the mGluR1-evoked current was seen in some PNs, and this effect was investigated further with more selective tyrosine and serine-threonine kinase inhibitors. The specific src tyrosine kinase inhibitor PP1 (Bishop et al., 2000 ) was used at $10 \mu \mathrm{M}$ in the patch pipette (with $0.1 \% \mathrm{DMSO}$ ). Figure $2 \mathrm{~A}$ shows an experiment with $10 \mu \mathrm{M}$ PP1 in which pulses of 80 and $30 \mu \mathrm{M}$ L-glutamate were released 30-60 sec apart every $10 \mathrm{~min}$, evoking maximal peak mGluR1 current at $80 \mu \mathrm{M}$ and 

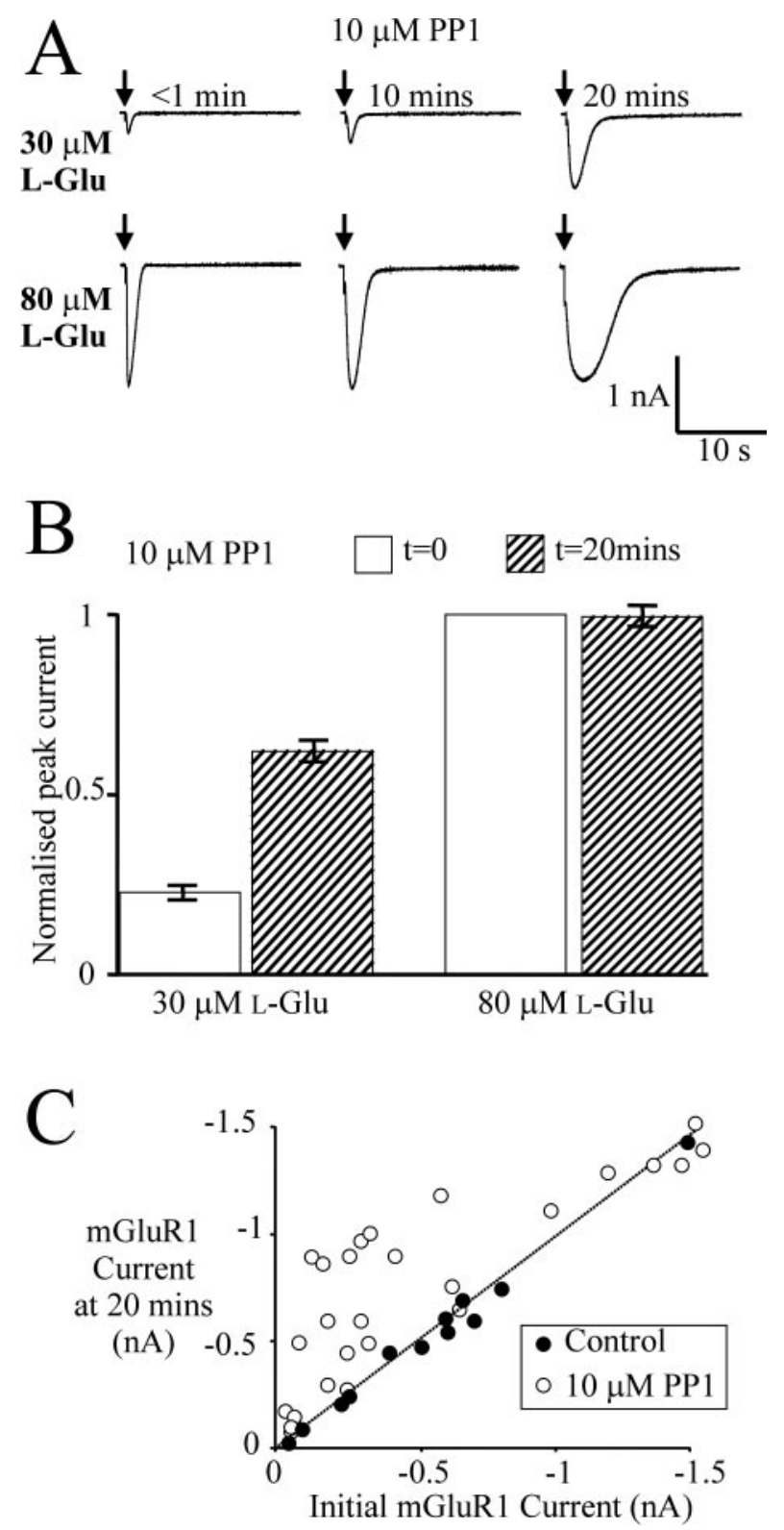

Figure 2. Potentiation of peak mGluR1-activated current by intracellular perfusion of $\mathrm{sic}$ kinase inhibitor PP1. Voltage clamp, $-75 \mathrm{mV}$. The concentrations are as follows: $50 \mu \mathrm{M} \mathrm{NBQX}, 50$ $\mu \mathrm{M} \mathrm{AP}-5,20 \mu \mathrm{m}$ bicuculline, $1 \mu \mathrm{m} \mathrm{TTX}$, and $0.25 \mu \mathrm{M}$ AGA4A. A, PN perfused internally with pipette solution containing $10 \mu \mathrm{m}$ PP1. Currents evoked by photorelease of $30 \mu \mathrm{m} \mathrm{L}$-glutamate (top traces) and $80 \mu \mathrm{m} \mathrm{L-glutamate} \mathrm{(bottom} \mathrm{traces)} \mathrm{at} 10 \mathrm{~min}$ intervals. $B$, Histogram of peak mGluR1 current at 20 min evoked by photorelease of 30 or $80 \mu \mathrm{m} \mathrm{L}$-glutamate normalized to the peak current in each cell recorded initially with $80 \mu \mathrm{m}$ L-glutamate. PP1 at $10 \mu \mathrm{m}$ perfused internally from the patch pipette. Open columns are initial current, and hatched columns are at $20 \mathrm{~min}$. Data are from six PNs. Peak currents evoked by photorelease of $30 \mu \mathrm{m} \mathrm{L}$-glutamate are potentiated after 20 min with PP1 ( $p<0.02)$, whereas those with $80 \mu \mathrm{m} \mathrm{L}$-glutamate are not. C, Summary plot of mGluR1 current evoked by photorelease of L-glutamate ( 30 or $80 \mu \mathrm{m}$ ) at 20 min against initial current in the same cell. Filled symbols, Control intracellular solution with $0.1 \%$ DMSO. Open symbols, Intracellular solution with $10 \mu \mathrm{MPP} 1,0.1 \%$ DMSO. Line drawn with unit slope to indicate correlation.

submaximal current at $30 \mu \mathrm{M}$. As can be seen, the peak current caused by $30 \mu \mathrm{M}$ increased approximately threefold after $20 \mathrm{~min}$ internal perfusion with PP1, whereas the current evoked by 80 $\mu \mathrm{M}$ L-glutamate remained at the same amplitude. The progressive increase in duration of responses with PP1, seen in Figure $2 \mathrm{~A}$, of 1.8 -fold over $20 \mathrm{~min}$ was present also in controls (half-maximum duration at $20 \mathrm{~min}$ in PP1, $4.3 \pm 1.0 \mathrm{sec}$; SEM; $n=5$; controls

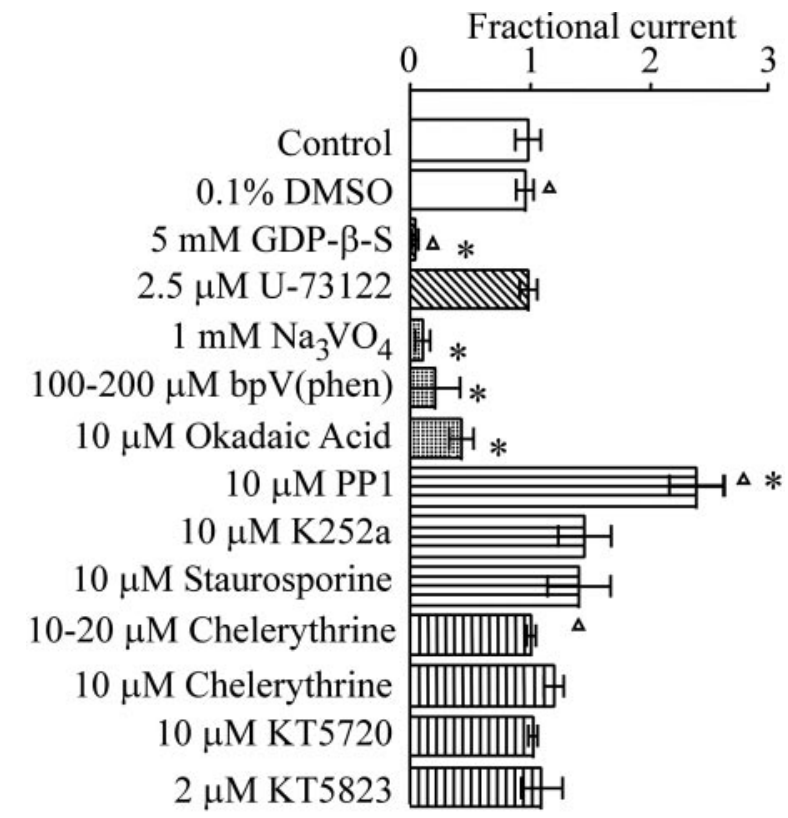

${ }^{\Delta}$ Intracellular perfusion $\quad * \mathrm{P}<0.02$

Figure 3. Summary of actions of signaling pathway inhibitors on the mGluR1-evoked current. Fractional mGluR1 current, normalized to the initial current, after 10 or 20 min extracellular application or 20 or $30 \mathrm{~min}$ intracellular perfusion (indicated with a triangle) of the different ligands at concentrations indicated. Open bars, Control, 0.1\% DMSO. Diagonal striped bars, GTPase inhibitor GDP $\beta$ S and PLC $\beta$ inhibitor U73122. Stippled bars, Phosphatase inhibitors. Horizontal striped bars, Tyrosine kinase inhibitors. Vertical striped bars, PKC, PKA, and PKG inhibitors. Mean \pm SEM, $4-25$ cells tested for each drug. ${ }^{*} p<0.02$ ( $t$ test).

with $0.1 \%$ DMSO, $5.5 \pm 1.3 \mathrm{sec}$ ). The results of similar experiments with PP1 in six PNs are displayed as a histogram in Figure $2 B$, in which peak current is normalized to the initial peak current evoked by $80 \mu \mathrm{M}$ L-glutamate in each cell. Peak currents evoked by $80 \mu \mathrm{M}$ glutamate showed no change over $20 \mathrm{~min}$ with $10 \mu \mathrm{M}$ PP1 internally, whereas those evoked by $30 \mu \mathrm{M}$ in the same cell showed potentiation by internal PP1 over $20 \mathrm{~min}$ by, on average, threefold. In two cells, after 20 min with PP1, $15 \mu \mathrm{M}$ L-glutamate produced submaximal peak currents approximately equal to the initial current evoked by $30 \mu \mathrm{M} \mathrm{L}$-glutamate, showing a twofold increase in L-glutamate sensitivity induced by PP1. Data from 25 cells with PP1 (open symbols) and 12 controls with $0.1 \%$ DMSO intracellularly (filled symbols) are shown in Figure $2 \mathrm{C}$ as the peak mGluR 1 current after $20 \mathrm{~min}$ whole-cell recording plotted against the current immediately after whole cell. The control cells showed no change in current at $20 \mathrm{~min}$ whether large or small initially, lying on the unit slope line. On the other hand, 17 PP1 cells with small initial current showed a large degree of potentiation (see also pooled data summarized in Fig. 3). The results show that PP1 produced no change in the maximum current that can be evoked by mGluR1 activation but increased the sensitivity to L-glutamate, shifting the concentration-conductance relationship to lower glutamate concentrations by a factor of approximately twofold.

\section{Serine-threonine kinase inhibitors}

The ability of serine-threonine kinase inhibitors to affect the mGluR1-activated current was tested in similar experiments. K252a and staurosporine inhibit both PTK and serine-threonine kinases when applied externally at the relatively high concentra- 
tions used here (Ruegg and Burgess, 1989) and produced no effect or small potentiation (in two of six PNs, on average, statistically nonsignificant) when tested on mGluR1 currents. Inhibitors of PKC (chelerythrine, 10 or $20 \mu \mathrm{M}$ ) (Herbert et al., 1990), PKA (KT5720, $10 \mu \mathrm{M}$ ) (Gadbois et al., 1992), or PKG (KT5823, 2 $\mu \mathrm{M}$ ) (Gadbois et al., 1992) present in the bath for $20 \mathrm{~min}$ had no effect on currents evoked by low (15-30 $\mu \mathrm{M})$ or high (70-90 $\mu \mathrm{M})$ L-glutamate concentration. Chelerythrine applied intracellularly (10 $\mu \mathrm{M}$ in the patch pipette) was also without significant effect at 30 and $80 \mu \mathrm{M}$ L-glutamate $(n=6 ; p>0.05)$. The data are summarized in Figure 3. These results with PTK and serine-threonine kinase inhibitors indicate that tyrosine phosphorylation but not serine-threonine phosphorylation is effective in reducing mGluR1 activation of the sEPSP cation conductance.

\section{Phosphatase inhibition}

Ligands that inhibit phosphatases were tested as inhibitors of the mGluR1 current. The nonspecific phosphatase inhibitor orthovanadate applied at $1 \mathrm{~mm}$ to the slice produced complete and reversible inhibition of the late mGluRl current and had no effect on the early glutamate transport current (Fig. $1 A$, top traces). However, orthovanadate also inhibits ATPases, and more selective reagents were used to test the role of phosphatases. Okadaic acid, a lipophilic phosphatase inhibitor that does not select between different phosphatases at the concentration used here (10 $\mu \mathrm{M}$ ) (Sugunuma et al., 1992), produced an irreversible partial inhibition of the mGluR1 current (Fig. $1 A$, bottom traces). The most effective reagents were water-soluble, organic vanadate derivatives reported to have selectivity for tyrosine phosphatases (Posner et al., 1994). One of these, bpV(phen), at $50 \mu \mathrm{M}$ produced a complete, reversible inhibition of the photolytically evoked mGluR1 current at low glutamate concentrations (30 $\mu \mathrm{M})$; however, at high glutamate concentration (80 or $160 \mu \mathrm{M})$ (Fig. $1 A$, middle traces), $200 \mu \mathrm{M} \mathrm{bpV(phen)} \mathrm{was} \mathrm{required.} \mathrm{The}$ results are summarized by the plot of peak current after $10 \mathrm{~min}$ incubation against glutamate concentration at $0,50,100$, and 200 $\mu \mathrm{M} \mathrm{bpV}$ (phen) (Fig. $1 B$ ).

Phosphatase inhibition was also effective in blocking activation of the sEPSC after PF stimulation. Records in Figure 4 show reversible block of the sEPSC evoked with tetanic PF stimulation ( 10 pulses at $50 \mathrm{~Hz}$ ) by orthovanadate $(0.5$ or $1 \mathrm{mM}$; mean \pm SEM of control, $0.05 \pm 0.03 ; n=3 ; p<0.02)$ and by bpV(phen) $(50$ $\mu \mathrm{M}$; mean \pm SEM of control, $0.11 \pm 0.07 ; n=4 ; p<0.02)$.

\section{G-protein inhibition}

A role for a GTPase in the PF sEPSC was shown by Tempia et al. (1998) by internal perfusion of PNs with GDP $\beta$ S. Experiments here in which the mGluR1 receptors were activated with photoreleased L-glutamate ( 45 or $90 \mu \mathrm{M}$ ) showed similar results. Groups of four PNs were tested with $0(15 \mathrm{~mm} \mathrm{LiCl})$ or $5 \mathrm{~mm}$ GDP $\beta S$ (trilithium salt) in the internal solution after $0,5,10,15$, and 30 min whole-cell perfusion. PNs perfused with GDP $\beta$ S showed a progressive loss of the mGluR1 conductance over $30 \mathrm{~min}$ as GDP $\beta S$ diffused through the dendritic tree, with magnitudes and time course similar to those seen by Tempia et al. (1998). The fractional current (mean \pm SEM) after $5,10,15$, and 30 min was $1.00 \pm 0.03,0.98 \pm 0.04,1.00 \pm 004$, and $0.96 \pm 0.04$, respectively, for control cells compared with $0.41 \pm 0.07,0.21 \pm 0.06$, $0.08 \pm 0.02$, and $0.03 \pm 0.03$, respectively, for cells loaded with 5 mM GDP $\beta$ S. The results, summarized in Figure 3, show inhibition of coupling between mGluR1 and the sEPSP channel by GDP $\beta$ S.

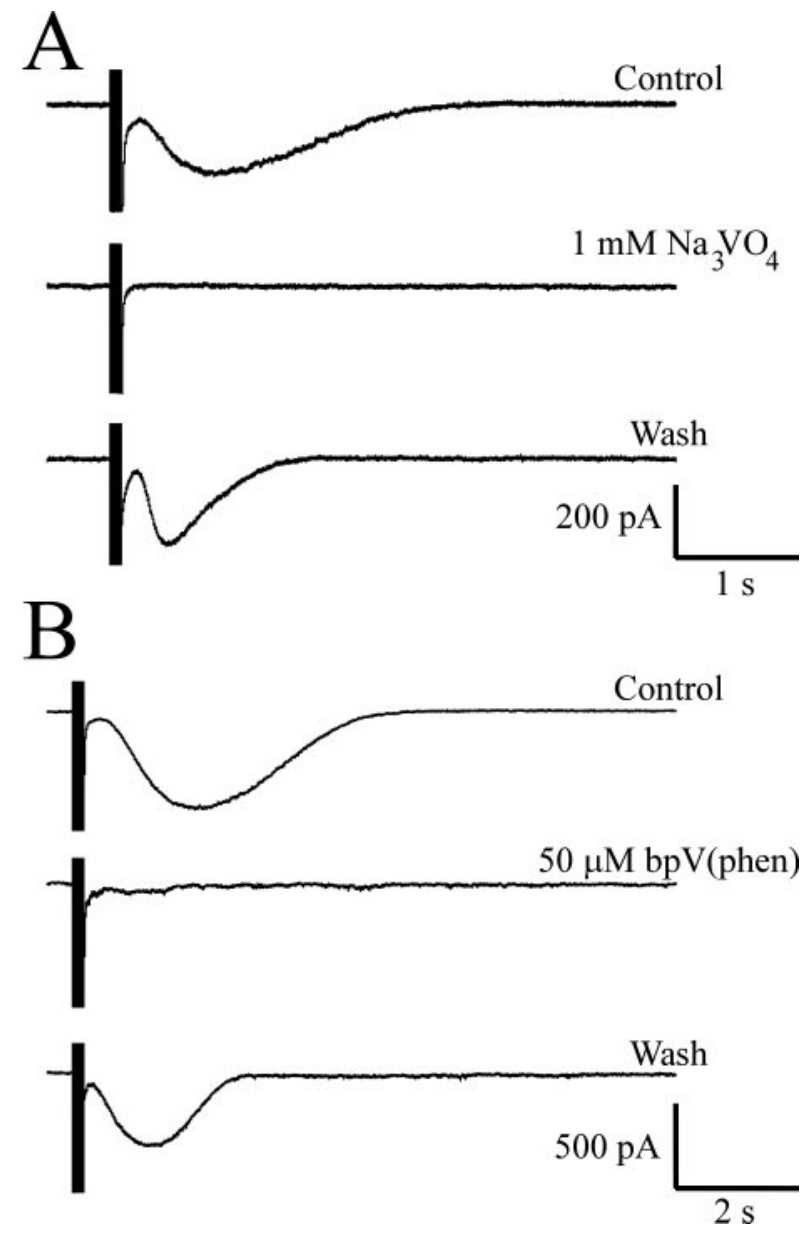

Figure 4. Effect of phosphatase inhibition on sEPSCs evoked by tetanic stimulation of PFs in transverse slices. Voltage clamp, $-75 \mathrm{mV} ; 20 \mu \mathrm{m} \mathrm{NBQX}, 20 \mu \mathrm{m}$ bicuculline, and $50 \mu \mathrm{m} \mathrm{AP-5}$ were present in bicarbonate saline with $5 \% \mathrm{CO}_{2} . A$, Ten pulses at $100 \mathrm{~Hz}$ before (top trace), in the presence of $1 \mathrm{~mm} \mathrm{Na}_{3} \mathrm{VO}_{4}$ (middle trace), and after 20 min wash (bottom trace). $B$, Ten pulses 50 $\mathrm{Hz}$ before (top trace), in the presence of $50 \mu \mathrm{m} \mathrm{bpV(phen)} \mathrm{(middle} \mathrm{trace),} \mathrm{and} \mathrm{after} 20$ min wash (bottom trace).

\section{Summary}

Data from five or more PNs for each of the reagents tested here are summarized in the bar graph of Figure 3, plotted as the glutamate-evoked mGluR1 current at 10 or 20 min incubation relative to the initial current. GDP $\beta$ S produced complete inhibition when applied at $5 \mathrm{~mm}$ internally for 20-30 min. As described previously (Canepari et al., 2001b) and shown in additional experiments here, the inhibitor of PLC $\beta, \mathrm{U} 73122$, had no effect at 2.5 and $5 \mu \mathrm{M}$, although this compound has been shown to be effective in inhibiting PLC $\beta 4$ (Cruzblanca et al., 1998; Haley et al., 2000), the isoform present in PNs (Sugiyama et al., 1999). The phosphatase inhibitors produced substantial or complete inhibition, in the case of $\mathrm{bpV}$ (phen) reversibly and specifically. Kinase inhibitors specific for tyrosine kinases, or nonselective inhibitors effective at PTK, produced overall potentiation of submaximal responses or no effect, whereas specific inhibitors of PKC, PKA, or PKG had no effect on peak mGluR1 current at high or low L-glutamate concentration in any experiments.

The G-protein, kinase, and phosphatase inhibitors tested did not produce significant changes in the peak amplitude of the current attributable to activation of glutamate transporter when compared with controls. The results show that, with $5 \mathrm{~mm}$ intracellular GDP $\beta S$ at $30 \mathrm{~min}$, transport current was $0.83 \pm 0.1$ 
(SEM; $n=4$ ) of the initial current, $10 \mu \mathrm{M}$ intracellular PP1 after 10 or $20 \min 0.91 \pm 0.05$ (SEM; $n=11$ ) of initial, and with 100 or $200 \mu \mathrm{M} \mathrm{bpV}$ (phen) at $15 \min 0.85 \pm 0.06(\mathrm{SEM} ; n=6)$ of initial. In controls, the transporter current at $30 \mathrm{~min}$ was $0.88 \pm 0.14$ (SEM; $n=6)$ of the initial amplitude.

\section{Discussion}

The mechanisms linking activation of mGluR1 receptors at $\mathrm{PN}$ spines of parallel fiber synapses to the cation channel underlying the slow EPSP have been elusive. The activation of PLC and generation of intermediates associated with intracellular $\mathrm{Ca}^{2+}$ release are unlikely candidates, first because $\mathrm{InsP}_{3}$ itself is relatively ineffective when photoreleased in PNs (Khodakhah and Ogden, 1995; Hirono et al., 1998; Watkins and Ogden 1999; Canepari et al., 2001b), and second, because $\mathrm{Ca}^{2+}$ release evoked by $\mathrm{InsP}_{3}$ activates inhibitory $\mathrm{Ca}^{2+}$-gated $\mathrm{K}^{+}$channels, not the excitatory $\mathrm{Na}^{+}$permeable channel of the sEPSC. Furthermore, inhibition of PLC by U73122 is ineffective in preventing the sEPSC and the mGluR1-activated conductance (Hirono et al., 1998; Tempia et al., 1998; Canepari et al., 2001b). The finding that PLC $\beta 4-$ deficient mice do not show the mGluR1-activated current (Sugiyama et al., 1999) was suggested by the authors to be attributable to a requirement for $\beta 4$ isoform of PLC to bind the $\mathrm{G}_{\alpha}$-protein subunit, stoichiometrically liberating $\beta \gamma$, which may activate the mGluR1 channel. In this case, the inability of U73122 inhibition of PLC $\beta 4$ to affect the mGluR1 current may indicate that U73122 does not affect the ability of PLC to bind G $\alpha$, unlike the effects of PLC $\beta 4$ deficiency. Although available evidence indicates that U73122 inhibits PLC $\beta 4$ (Cruzblanca et al., 1998; Haley et al., 2000), there are no internal controls that can be used in PNs to verify this.

The effects reported here, of PTK inhibitors augmenting and phosphatase inhibitors inhibiting mGluR1 activation of the channel, suggests that tyrosine phosphorylation of a protein in the activation pathway decreases the level of activation. The most striking effects on the mGluR1-evoked current observed in the course of this study were potentiation of submaximal but not maximal mGluR1 responses by the selective $s r c$ kinase inhibitor PP1 and inhibition by the PTP inhibitor bpV(phen). PP1 has been reported previously to be ineffective on the $(R S)-3,5$ dihydroxyphenylglycine (DHPG)-activated mGluR1 current in PNs (Boxall, 2000), but no distinction was made between effects on maximal and submaximal concentrations of DHPG, and the DHPG application was slow, unlike the $1 \mathrm{msec}$ photolytic application of glutamate used here. PTK reagents K252a and staurosporine were used here at high concentrations, in which selectivity is compromised, but were also effective in potentiating the mGluR1 current in a small proportion of experiments. In contrast, specific PKA, PKC, and PKG inhibitors were ineffective at low and high glutamate concentrations. An additional incidental observation is that the inability of trkB inhibitor K252a (Kafitz et al., 1999) to block the mGluR1-activated current provides evidence that neurotrophins released by neighboring cells in response to mGluR activation are not involved in the generation of the PN mGluR1 current.

In hippocampal CA3 neurons, there is evidence that protein tyrosine phosphorylation activates an excitatory cation conductance (Heuss et al., 1998). In contrast to the results reported here, in CA3 neurons, PTK inhibition prevented activation of an mGluR1 cation conductance and was shown to be independent of G-protein coupling. The inhibition in PNs by GDP $\beta$ S shows that a G-protein is involved in the $\mathrm{PN}$ signaling pathway (Tempia et al., 1998), and it has been shown that $\mathrm{G}_{\mathrm{q}}$-deficient mice are deficient in PLC $\beta$ signaling and also have no sEPSC on tetanic PF stimulation (Hartmann et al., 2002). Thus, the PN mGluR1 conductance differs from that in hippocampal CA3, the PNs inhibited by tyrosine phosphorylation and the CA3 enhanced, and the PNs requiring one or more $G$-proteins, including $G_{q}$.

The point in the activation cascade at which tyrosine phosphorylation-dephosphorylation may regulate the mGluR1 conductance is of interest. The potentiation by PP1 of the mGluR1activated conductance at submaximal but not at maximal levels of mGluR1 activation indicates that PTK phosphorylation does not influence the final opening-closing conformational rates of the channel or the single-channel conductance. Evidence from current noise analysis of the mGluR1-activated conductance (Canepari et al., 2001b; our unpublished data) suggests that the open probability of the mGluR1-activated channel is small even at maximal activation. Thus, if channel tyrosine phosphorylation-dephosphorylation modifies maximum open probability or single-channel conductance, the maximal as well as submaximal peak currents should be affected. The results here therefore indicate that tyrosine phosphorylation is upstream of the channel open-closed reaction. The effect of PTK inhibition was to increase apparent mGluR1 affinity twofold, indicating that PTK phosphorylation increases the glutamate concentrations required for activation twofold. Similarly PTP inhibition by bpV(phen) was found to block the mGluR1-activated conductance more effectively at low glutamate concentrations. Evidence of tyrosine phosphorylation has been seen at two sites in other mGluR1- $\mathrm{G}_{\mathrm{q}}$ systems. Phosphorylation of group I mGluRs by G-protein receptor kinases has been reported to produce desensitization by uncoupling receptors from heterotrimeric G-proteins (Dale et al., 2000), and a tyrosine phosphorylation of $\mathrm{G}_{\mathrm{q}}$ has been shown with muscarinic receptor activation, reducing activity to $50 \%$ of control (McCrary et al., 2002). A tyrosine phosphatase, PTPMEG, has been shown by immunoprecipitation to be associated with the PN-specific glutamate receptor GluR $\delta_{2}$ (Hironaka et al., 2000) present at high density in spines and which itself has properties similar to the mGluR1-activated cation channel (Canepari et al., 2002).

The observations here that inhibition of phosphatase can prevent the postsynaptic mGluR1 current and PF sEPSC and that inhibition of PTK increases the sensitivity to mGluR1 activation show that tyrosine phosphorylation is able to turn the signaling pathway fully on and off and may function in this way during mGluR1 signaling. However, it is more likely that PTK-PTP pathways modify an unidentified primary signaling mechanism between mGluR1 and the sEPSP ion channel. Possible interactions are with $\mathrm{Ca}^{2+}$-dependent kinase-phosphatase systems that may contribute to regulation of the sEPSP, for example the increase of sEPSP amplitude with previous depolarization or CF stimulation attributed to elevated $\mathrm{Ca}^{2+}$ (Batchelor and Garthwaite, 1997), and an interaction with the PKG-G-substrate phosphatase inhibitor (Hall et al., 1999) associated with PF stimulation.

\section{References}

Aiba A, Kano M, Chen C, Stanton ME, Fox GD, Herrup K, Zwingman TA, Tonegawa S (1994) Deficient cerebellar long-term depression and impaired motor learning in mGluR1 mutant mice. Cell 79:377-388.

Batchelor AM, Garthwaite J (1997) Frequency detection and temporally dispersed synaptic signal association through a metabotropic glutamate receptor pathway. Nature 385:74-77.

Bishop AC, Ubersax JA, Petsch DT, Matheos DP, Gray NS, Blethrow J, Shimizu E, Tsien JZ, Schultz PG, Rose MD, Wood JL, Morgan DO, Shokat 
KM (2000) A chemical switch for inhibitor-sensitive alleles of any protein kinase. Nature 407:395-401.

Boxall AR (2000) GABAergic mIPSCs in rat cerebellar Purkinje cells are modulated by TrkB and mGluR1-mediated stimulation of Src. J Physiol (Lond) 524:677-684.

Canepari M, Ogden D (2002) Evidence for protein tyrosine kinase/phosphatase regulation of the parallel fibre sEPSP of rat cerebellar Purkinje neurones. Pflügers Arch 443:S302.

Canepari M, Nelson L, Papageorgiou G, Corrie JE, Ogden D (2001a) Photochemical and pharmacological evaluation of 7-nitroindolinyl- and 4-methoxy-7-nitroindolinyl-amino acids as novel, fast caged neurotransmitters. J Neurosci Methods 112:29-42.

Canepari M, Papageorgiou G, Corrie JE, Watkins C, Ogden D (2001b) The conductance underlying the parallel fibre slow EPSP in rat cerebellar Purkinje neurones studied with photolytic release of L-glutamate. J Physiol (Lond) 533:765-772.

Canepari M, Bellamy TC, Sesay A, Magnus C, Kuner T, Ogden D (2002) Evidence from channel properties and pore-blocking drugs that glutamate channel delta 2 underlies the metabotropic slow EPSP in cerebellar Purkinje neurones. J Physiol (Lond) 543P:32.

Cruzblanca H, Koh DS, Hille B (1998) Bradykinin inhibits M current via phospholipase $\mathrm{C}$ and $\mathrm{Ca}^{2+}$ release from IP3-sensitive $\mathrm{Ca}^{2+}$ stores in rat sympathetic neurons. Proc Natl Acad Sci USA 95:7151-7156.

Dale LB, Bhattacharya M, Anborgh PH, Murdoch B, Bhatia M, Nakanishi S, Ferguson SS (2000) G protein-coupled receptor kinase-mediated desensitization of metabotropic glutamate receptor 1A protects against cell death. J Biol Chem 275:38213-38220.

Gadbois DM, Crissman HA, Tobey RA, Bradbury EM (1992) Multiple kinase arrest points in the G1 phase of nontransformed mammalian cells are absent in transformed cells. Proc Natl Acad Sci USA 89:8626-8630.

Haley JE, Abogadie FC, Fernandez-Fernandez JM, Dayrell M, Vallis Y, Buckley NJ, Brown DA (2000) Bradykinin, but not muscarinic, inhibition of $\mathrm{M}$-current in rat sympathetic ganglion neurons involves phospholipase C- $\beta 4$. J Neurosci 20:RC105(1-5).

Hall KU, Collins SP, Gamm DM, Massa E, DePaoli-Roach AA, Uhler MD (1999) Phosphorylation-dependent inhibition of protein phosphatase-1 by G-substrate. A Purkinje cell substrate of the cyclic GMP-dependent protein kinase. J Biol Chem 274:3485-3495.

Hartmann J, Blum R, Kovalchuk Y, Kuner R, Durand GM, Miyata M, Kano M, Offermanns S, Konnerth A (2002) Gq-dependence of mGluRmediated synaptic signaling in cerebellar Purkinje cells. Soc Neurosci Abstr 28:339.15.

Herbert JM, Augereau JM, Gleye J, Maffrand JP (1990) Chelerythrine is a potent and specific inhibitor of protein kinase C. Biochem Biophys Res Commun 172:993-999.

Heuss C, Scanziani M, Gahwiler BH, Gerber U (1999) G-proteinindependent signalling mediated by metabotropic glutamate receptors. Nat Neurosci 2:1070-1077.
Hironaka K, Umemori H, Tezuka T, Mishina M, Yamamoto T (2000) The protein-tyrosine phosphatase PTPMEG interacts with glutamate receptor delta 2 and epsilon subunits. J Biol Chem 275:16167-16173.

Hirono M, Konishi S, Yoshioka T (1998) Phospholipase C-independent group I metabotropic glutamate receptor-mediated inward current in mouse Purkinje cells. Biochem Biophys Res Commun 251:753-758.

Kafitz KW, Rose CR, Thoenen H, Konnerth A (1999) Neurotrophin-evoked rapid excitation through TrkB receptors. Nature 401:918-921.

Khodakhah K, Ogden D (1995) Fast activation and inactivation of inositol trisphosphate-evoked $\mathrm{Ca}^{2+}$ release in rat cerebellar Purkinje neurones. J Physiol (Lond) 487:343-358.

McCrary K, Wecker L, Pacheco MA (2002) In SH-sy5y cells endogenous $\mathrm{Gq} / 11$ is tyrosine phosphorylated. Soc Neurosci Abstr 28:141.2.

Napper RM, Harvey RJ (1988) Number of parallel fibre synapses on an individual Purkinje cell in the cerebellum of the rat. J Comp Neurol 274:168-177.

Papageorgiou G, Ogden DC, Barth A, Corrie JET (1999) Photorelease of carboxylic acids from 1-acyl-7-nitroindolines in aqueous solution: rapid and efficient photorelease of L-glutamate. $\mathrm{J}$ Am Chem Soc 121:6503-6504.

Posner BI, Faure R, Burgess JW, Bevan AP, Lachance D, Zhang-Sun G, Fantus IG, Ng JB, Hall DA, Lum BS, Shaver A (1994) Peroxovanadium compounds. A new class of potent phosphotyrosine phosphatase inhibitors which are insulin mimetics. J Biol Chem 269:4596-4604.

Quilitzsch U, Wieghardt K (1979) Kinetics of the Diperoxovanadate(V)Monoperoxovanadate $(\mathrm{V})$ conversion in perchloric acid media. Inorg Chem 18:869-871.

Ruegg UT, Burgess GM (1989) Staurosporine, K-252 and UCN-01: potent but nonspecific inhibitors of protein kinases. Trends Pharmacol Sci 10:218-220.

Sillevis-Smitt P, Kinoshita A, De Leeuw B, Moll W, Coesmans M, Jaarsma D, Henzen-Logmans S, Vecht C, De Zeeuw C, Sekiyama N, Nakanishi S, Shigemoto R (2000) Paraneoplastic cerebellar ataxia due to autoantibodies against a glutamate receptor. $\mathrm{N}$ Engl J Med 342:21-27.

Suganuma M, Fujiki H, Okabe S, Nishiwaki S, Brautigan D, Ingebritsen TS, Rosner MR (1992) Structurally different members of the okadaic acid class selectively inhibit protein serine/threonine but not tyrosine phosphatase activity. Toxicon 30:873-878.

Sugiyama T, Hirono M, Suzuki K, Nakamura Y, Aiba A, Nakamura K, Nakao K, Katsuki M, Yoshioka T (1999) Localization of phospholipase C beta isozymes in the mouse cerebellum. Biochem Biophys Res Comm 265:473-478.

Tempia F, Miniaci MC, Anchisi D, Strata P (1998) Postsynaptic current mediated by metabotropic glutamate receptors in cerebellar Purkinje cells. J Neurophysiol 80:520-528.

Watkins C, Ogden D (1999) Excitation of Purkinje cells in rat cerebellar slices by metabotropic glutamate receptor agonists. J Physiol (Lond) 515P:128 